\title{
Adaptive Environmental Governance of Changing Social-ecological Systems: Empirical Insights from the Okavango Delta, Botswana
}

\author{
Author information: \\ Jamie E. Shinn, Ph.D. \\ Department of Geology \& Geography \\ West Virginia University \\ 330 Brooks Hall \\ 98 Beechurst Ave. \\ Morgantown, WV 26506 \\ Telephone: 406-599-6479 \\ Email: jamieshinn@gmail.com
}

Acknowledgements:

Research for this project was funded by the United States National Science Foundation (BCS/GSS Doctoral Dissertation Research Improvement Award-1234018) and the Fulbright Foundation. I wish to acknowledge the Government of Botswana for permission to conduct this research. I would also like to recognize the Okavango Research Institute of the University of Botswana for providing me with institutional affiliation while conducting fieldwork for this project. I offer my sincerest thanks to my Research Assistants Fuata John and Kentse Madise for their vital assistance with fieldwork for this project. I am grateful to Brian King for generous feedback on previous versions of this manuscript. Thank you to Jayme Walenta and two anonymous reviewers for valuable suggestions on how to improve this paper. Thanks also to Michelle Lenze for her assistance with the creation of Figure 1. Finally, thank you to the Department of Geography at Texas A\&M University, where some of this paper was written. 


\section{Adaptive Environmental Governance of Changing Social-ecological Systems: Empirical Insights from the Okavango Delta, Botswana}

\section{Introduction}

Increased environmental variability as a result of climate change will continue to intensify in coming decades, with particularly acute consequences for those living in already marginal conditions (Ensor et al. 2015; IPCC 2014; Kuruppu and Liverman 2010; Pelling 2010). The impacts of these biophysical changes require new approaches to environmental governance to facilitate successful forms of climate change adaptation for individuals and communities in changing social-ecological systems (SES). Governance systems must account for not only what is known and predicted about the future, but also for the "deep uncertainty" about what the future will hold (Haasnoot et al. 2013). Existing work from adaptive management and related fields has effectively theorized new governance strategies that embrace complexity and are able to effectively respond to changing and uncertain biophysical dynamics (Bakker and Morinville 2013; Bogardi et al. 2012; Huitema et al. 2009; Pahl-Wostl 2007; Ostrom 2007). However, these theorizations often lack attention to important on-the-ground realities, including the feasibility of implementation and issues of power within multi-scalar environmental governance systems (Eriksen et al. 2015; Bakker and Morinville 2013).

Environmental governance is the "set of regulatory processes, mechanisms, and organizations through which political actors influence environmental actions and outcomes" (Lemos and Agrawal 2006, 298). Environmental governance systems are comprised of both formal and informal social institutions, which are defined of as the "socially accepted rules that determine access to natural resources" (Ellis 1999, 131). Rules may be formal or customary in origin (ibid.). These institutions determine how access to natural resources is governed (Leach et al. 1999) and how governance systems will respond to increased environmental variability as the result of climate change (Eriksen et al. 2015; Agrawal 2010; Boko et al. 2007). Under conditions of environmental change, environmental governance systems and their related social institutions have the potential to build adaptive capacity or to limit the present and future adaptive capacity of certain actors.

Adaptive management is based on the idea that environmental governance systems should have the ability to change practices based on new insights and experiences, especially considering that future events are difficult to accurately predict and plan for (Pahl-Wostl 2007). Adaptive management practices allow for experimentation within an SES to gain feedback and make necessary changes before negative outcomes occur (Ostrom 2007). The related polycentric governance approach involves several independent actors within adaptive management systems that are able to effectively respond to change and uncertainty (Bakker and Morinville 2013; Ostrom 2010; Pahl-Wostl 2009; Huitema et al. 2009; Folke et al. 2005; Ostrom et al. 1961). Ideally these actors are an integration of formal and informal institutions, which leads to higher adaptive capacity for resource management and governance systems (Pahl-Wostl 2009). Proponents of this approach embrace complexity and use it as a way to make decisions, rather than as an excuse for inaction (Bakker and Morinville 2013). This is believed to foster "learning by doing" (Bakker and Morinville 2013) or "learning to manage by managing to learn" (PahlWostl 2009). Advocates of polycentric governance argue that these systems are more resilient to climate change than mono-centric systems because they are better equipped to respond 
effectively to uncertainty (Pahl-Wostl and Knieper 2014; Bakker and Morinville 2013; Bogardi et al. 2012; Huitema et al. 2009).

However, there remains a need for more systematic research on how polycentric and adaptive governance systems operate in specific settings, including on the roles of governmental and nongovernmental actors (Pahl-Wostl and Knieper 2014). Indeed, a number of scholars have suggested that adaptive governance approaches should not be considered a panacea (Ostrom 2010; Armitage et al. 2008), but rather should be treated as "one potential tool in a suite of governance options" (Armitage et al. 2008b, 100). Of particular importance to the arguments being advanced in this paper, Bakker and Morinville $(2013,7)$ highlight three potential problems with adaptive governance systems. First, the feasibility of implementing such strategies is questionable, particularly in places with limited resources (ibid.). Second, a focus on adaptive management might increase attention to adaptation at the expense of important mitigation efforts (ibid.). Third, adaptive management systems have the potential to occlude power dynamics between the actors involved in governance (ibid.). In particular, there is potential for state and international level policies to override local adaptive efforts and undermine existing informal risk management strategies (Eakin et al. 2014). Further, environmental governance strategies can have differential impacts within communities, due to uneven adaptive capacities and power relations at the local scale (Goldman and Riosmena 2013). As such, more attention is needed to how power dynamics within multi-scalar environmental governance systems impact adaptation possibilities for all actors (Eriksen et al. 2015).

This paper offers empirically grounded insights on adaptive management from a research project in the Okavango Delta, Botswana. This dynamic wetland ecosystem provides a critical source of water for Northwest Botswana (Mosepele et al. 2009). Many of the livelihood strategies used by residents or this rural region are dependent on wetland resources (King et al. 2016; Bedsen and Meyer 2003) and are designed to respond to some level of environmental variability (Kgathi et al. 2007). This includes the practice of transitioning between dryland and floodplain agriculture (known locally as molapo farming) in response to flooding and drought (Motsholapheko et al. 2012; Magole and Thapelo 2005). In 2009-2011, higher than average floods inundated many floodplain fields past the point of production, causing many molapo farmers and others living near the floodplain to transition temporarily to dryland areas (Shinn et al. 2014). At the same time, the highly centralized Government of Botswana (GOB) began to enforce stricter regulations over access to wetland resources. Some of these regulations originated with a new adaptive management plan developed for the region. Many residents felt that these regulations threatened the viability of their preferred wetland and transitional livelihood practices. Findings from the project thus reveal that top-down government responses to flooding variability in this region are undermining adaptive management efforts and are reducing the adaptive capacity of many residents. Drawing on these findings, the central argument of this paper is that adaptive management efforts must better attend to the complex relationships between changing biophysical dynamics and the unequal power relations within multi-scalar systems of environmental governance. 


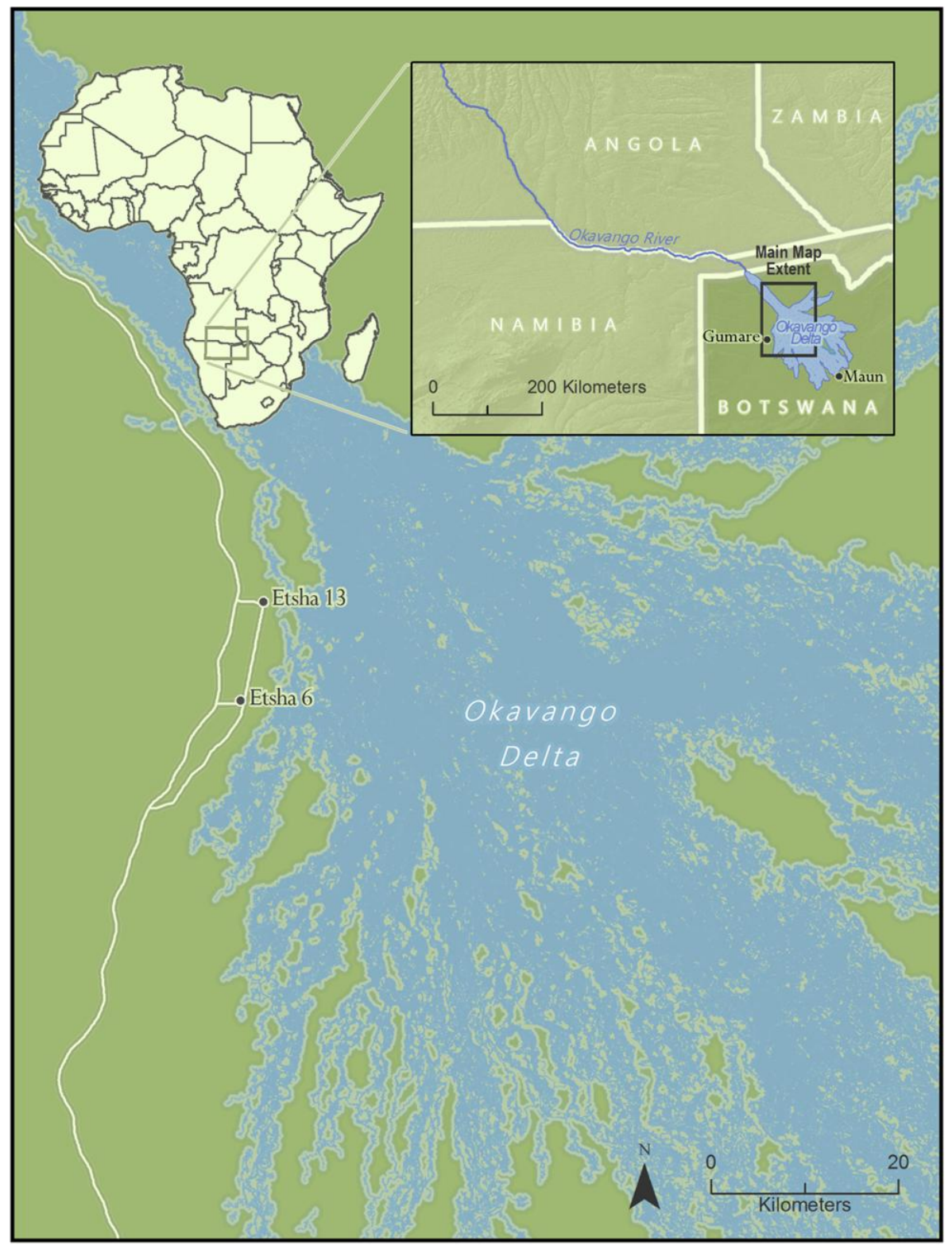

Figure 1. Okavango Delta, Botswana, including study sites 


\section{Background}

2.1. Centralized environmental governance in Botswana

Botswana is often touted as an African success story, sometimes even referred to as "The African Miracle" (Taylor 2006; Taylor 2003; Samatar 1999). While the country has indeed had a number of political and economic successes, it still faces significant challenges. This includes an unequal distribution of political power, which has been concentrated with the Botswana Democratic Party (BDP), in power since independence with no viable opposition to date (Hillbom 2008; Taylor 2003). The BDP has maintained a highly centralized state government, including in relation to natural resource management and environmental governance (Hoon 2014; Motsumi and Cassidy 2012; Magole 2008).

Two government ministries are particularly important to environmental governance in Botswana. First, the Ministry of Environment, Wildlife, and Tourism (MEWT) is tasked with overseeing environmental and natural resource management in the country. A number of important Departments are housed under MEWT, including the Department of Environmental Affairs (DEA). The DEA is the governing body for wetland management in the Okavango Delta. Second is the Ministry of Local Government (MLG), which is mandated "to deliver effective local governance, social services, social protection and basic infrastructure by creating an enabling environment for improvement of the quality of lives of [citizens]" (MLG 2014). The Tribal Authority and the Land Board are housed under the MLG. The Tribal Authority is part of the national government, but is connected to traditional chiefs (singular kgosi, plural dikgosi) and the traditional court system (kgotla). The Chieftainship Act of 1987 gave the government formal authority over the dikgosi and established "complete supremacy of the central government over the traditional leaders of Botswana" (Sharma 2005, 3). As a result, Botswana law now requires dikgosi to carry out instructions given to them by the GOB, including those related to natural resource access and environmental management. While dikgosi are still elected in customary fashion at kgotla meetings, a designated government minister must also formally recognize their appointment and has the power to remove the dikgosi from office (Sharma 2005, 5). As such, the Tribal Authority remains a governing institution in Botswana, but its autonomous power has been steadily reduced over time. Soon after independence from Britain in 1966, the new government established regional Land Boards, which also assumed some of the traditional responsibilities of the dikgosi, including land allocation (DeMotts et al. 2009). At this time, the GOB designated three types of formal land tenure for the country, which are still in place today: tribal (communal) land, state land (usually for protected areas), and commercial land (for private use, often for large-scale grazing). While tribal land in Botswana is "communally owned," it is "held in trust for communities" by regional Land Boards, as outlined in the Tribal Land Act of 1968 (DEA 2008). Tribal land is never sold, but is rather leased to citizens in 99-year increments by the Land Boards (ibid.). As discussed in section 4, each of these institutions has significant influence over how the environment is governed in Botswana.

\subsection{Decentralization efforts in Botswana}

There have been some notable efforts to decentralize environmental governance in Botswana, specifically in relation to Community Based Natural Resource Management (CBNRM) efforts. However, these attempts have been described as "ambiguous" and "weak" and have largely resulted in a re-centralization of power over time (Hoon 2014; Poteete and Ribot 2011). CBNRM programs were first popularized in the country in the 1980s in an effort to promote conservation 
through providing people benefits from wildlife and other natural resources (Poteete and Ribot 2011; Nelson and Agrawal 2008). In reality, the cumbersome policies and expensive fees necessary to establish tourism ventures were barriers to local communities, and much of the control over these projects ended up with Land Boards, government ministries, and high-end tour operators (Poteete and Ribot 2011). While Community Based Organizations (CBO) were established to help mitigate these issues, these groups have been plagued by accusations of corruption and mismanagement of resources (Poteete and Ribot 2011). As a result, governance of CBNRM programs has largely ended up being top-down in nature and over time control have been re-centralized with the political elite, especially within MEWT (Hoon 2014; Nelson and Agrawal 2008). This is particularly well demonstrated by a 2007 policy that placed 65 percent the of revenues generated from CBNRM projects into a national conservation fund, with only 35 percent going to the community organizations that house the projects (Hoon 2014; Poteete and Ribot 2011). This was allegedly in response to mismanagement at the community scale, but it has also been found that government officials exaggerate these issues in an effort to regain power (Poteete and Ribot 2011). As a result, Hoon $(2014,66)$ argues Botswana's current approach to CBNRM "... has transformed what was supposed to be a bottom up and participatory approach to empower rural communities... into a mechanism for the central government for managing relations between local communities and the private sector." Of note, the GOB released broad decentralization policy plans in April 2014, but it remains to be seen whether and how they will be implemented (GOB 2014).

\subsection{The Okavango Delta Management Plan}

The Okavango Delta is a wetland of international significance and environmental governance of the Delta is tied to international level edicts. The Okavango Delta is one of the largest sites protected under the Intergovernmental Ramsar Convention on Wetlands and the United Nations Educational, Scientific and Cultural Organization (UNESCO) recently designated it as a World Heritage Site. The Ramsar Convention is an intergovernmental treaty whose mission is "the conservation and wise use of all wetlands through local, regional and national actions and international cooperation, as a contribution towards achieving sustainable development throughout the world" (RCS 2006, 6). The Delta was officially listed as a Ramsar site in 1996, with an official area of 5,537,400 ha (RIS 2006, 1). Joining the Ramsar Convention prompted the GOB to develop and implement the Okavango Delta Management Plan (ODMP).

The ODMP is a strategic plan developed from 2003-2006 to create sustainable management practices in the Ramsar site, and was partially funded with seed money from the Ramsar organization. The ODMP's vision is "A carefully managed, well functioning ecosystem that equitably and sustainably provides benefits for local, national, and international stakeholders" (DEA 2008, xvi). The ODMP has been described as a first step in adaptive management for the Okavango Delta, as it explicitly recognizes the need to respond to the high level of uncertainty of the Delta ecosystem, involved local stakeholders in the development of the Plan, and established District Councils to provide leadership and oversight at the regional level (Motsumi and Cassidy 2012). However, even given these successes, Motsumi and Cassidy $(2012,283)$ question the actual devolution of authority in these new governance arrangements and note "active adaptive management as an explicit approach has not translated into daily management activities..." This includes a lack of dynamic responses to the higher than normal floods of 2009-2011 (ibid.). Elsewhere it has been noted that while local stakeholders were successfully involved in the 
planning processes of the ODMP, the central government continues to control actual decisionmaking (Magole 2008). This is at least in part because local entities lack the financial and human resource capacity to successfully implement plans such as the ODMP at the local level (ibid.)

As discussed in section 4, this research further confirm that while the ODMP has had some successes related to adaptive management, much like past CBNRM efforts in the country, it has ultimately resulted in the continuation of a centralized and top-down approach to environmental governance in the Okavango Delta. Of particular importance to this project, the ODMP states, "Land use in ecologically vulnerable areas, such as molapo farming and resource harvesting, should be subjected to more intensive management, monitoring and enforcement" (DEA 2008, 123). The ODMP goes on to suggest prohibiting "any development within 200 [meters] from the floodplain for the whole country." Attempts to locate the origin of the 200 -meter rule were unsuccessful. As such, it is unknown if this rule is based on specific understandings of floodplain ecology in Botswana or is an arbitrary number settled upon by the GOB and taken up by the ODMP. Regardless of where the rule originated, it is resulting in restricted access to molapo fields in this region, as discussed in section 4.3.

\subsection{Flooding variability in the Okavango Delta}

The Okavango Delta is characterized by spatially and temporally variable flooding patterns. The water of the Delta originates from rainfall in the highlands of Angola, and to a lesser extent with local precipitation events (McCarthy et al. 2000). Flooding events in the Okavango Delta are generally biannual, but are relatively unpredictable in time and space (Neuenschwander and Crews 2008; Heinl et al. 2006; Wolski et al. 2006; Gumbricht et al. 2001; McCarthy et al. 2000). As a result of temporal and spatial variability, villages can experience changes in their proximity to water, the amount of water present near their homes and agricultural fields, and the timing of the arrival of water, both within and between years. There are three major hydro-ecological zones of the Delta: permanent swamp, seasonal (regularly flooded) floodplains, and occasional floodplains (Wolski and Savenije 2006). The major river channels of the interior of the Delta are lined with vegetation that is permeable to water (Gumbricht et al. 2004). As a result, water constantly leaks from these channels to create permanent swamp areas (ibid.). When the floods expand beyond the swamps, they infiltrate dry ground and raise the level of the groundwater table (Gumbricht et al. 2004, 180). The depth of the groundwater table at the time of flooding is a major factor in determining the extent of inundation of the floodplain in a given year (ibid.). Even though flooding and precipitation events are not synced in the Okavango Delta, they are connected. Whereas the rainy season in the Delta typically occurs between November and March (Wolski and Savenije 2006), floods usually reach their peak around mid-August (Gumbricht et al. 2004). As Gumbricht et al. (2004, 180) state, "Good summer rains raise the groundwater table, and hence contribute to increasing the area of inundation during the seasonal flood." If the water table is still high from the previous year of flooding, even moderate inflow can result in extensive inundation (ibid.).

While flooding variability is an inherent part of Delta system, floods during 2009-2011 brought more water than in many decades and had distinct spatial patterns from previous floods. These flooding events had important consequences for wetland livelihoods in the region, as discussed in section 4.1. The Okavango Research Institute (ORI) reports that inflow at Mohembo, the inlet of the Delta at the Namibian border, increased from $9,800 \mathrm{~mm}^{3} /$ year in 2007 to over 13,300 
$\mathrm{mm}^{3} /$ year in 2011 (Wolski 2012). It is important to note that these floods were the fourth highest on record (kept since 1934) (ibid.) and do not necessarily represent new levels of environmental variability. Indeed, characterizing new levels of variability in the Delta is challenging, given the dearth of long-term climate data for the region (McCarthy 2000). As such, this research project focused on understanding how governance systems responded to these increases in flooding, whether these changes were part of a long-term cycle, represented new levels of variability due to climate change, or were a combination of these dynamics.

Regardless of whether the floods of 2009-2011 represent a new level of variability, recent research indicates a perception of decreased predictability of precipitation and flooding patterns in the region of the study site for this project (King et al. 2016). Moreover, climate models for this region predict future increases in environmental variability as a result of climate change. The Fifth Assessment Report (AR5) of the Intergovernmental Panel on Climate Change (IPCC) indicates that in the coming decades the region of the Okavango Delta is likely to experience threats to food security, increased risk of diseases, higher temperatures, and increases in extreme weather events such as droughts and floods (Niang 2014). The $A R 5$ reports there are already observed trends toward warmer temperatures and less precipitation in southern Africa, as well as intra-seasonal changes in duration, frequency, and intensity of rainfall (Niang 2014, 1209). Further, the IPCC forecasts that this area is very likely to experience a significant decrease in precipitation and an increase in severe droughts by the middle of this century (ibid.). While some climate models predict drier conditions for the Okavango Delta specifically (Niang 2014; Milzow et al. 2010), other models have shown the potential for either wetter or drier conditions in the future (Wolski and Murray-Hudson, 2008). As such, it is certain that climate change will impact this social-ecological system, but the nature and magnitude of those impacts is difficult to accurately predict (ibid.; Murray-Hudson et al. 2006; Andersson et al. 2006). There is currently no coordinated plan for adaptation in Botswana (Motsholapheko et al 2015), including for flooding events (Motsumi and Cassidy 2012).

\section{Study Sites and Methods}

\subsection{Study sites}

Approximately 175,000 people live in the North-West District of Botswana, which encompasses the entire Okavango Delta and the surrounding region (CSO 2011). The study sites for this project were the villages of Etsha 6 and Etsha 13 (see Figure 1). The Etsha region is a narrow strip of land of approximately $260 \mathrm{~km}^{2}$ that runs north to south along the western edge of the Delta; it is comprised of 13 villages (Etsha 1-Etsha 13). The first people to settle the villages were refugees fleeing the Angolan civil war in the late 1960s. These communities now consist of the refugees, their offspring, and other residents from Botswana who have chosen to settle there The thirteen Etsha villages are similar in many ways, including in their histories of development, ethnic makeup, household demographics, governance structures, and livelihood practices. Etsha 6 is centrally located and is the largest of the villages. It is the location of the region's primary health clinic, secondary school, food co-op, head chief's office, and kgotla. This makes it an important hub of social and political life for all 13 of the Etsha villages. According to the 2011 census, the population of Etsha 6 is 3,130 (CSO 2011). Etsha 13 is the northernmost of the villages and is located in closest proximity to the floodplain. According to the 2011 census, it has a population of 2,377 (CSO 2011). 
Etsha 6 and Etsha 13 offer two important insights. First, the villages are located in the region of the Delta most severely impacted by the high floods of 2009-2011 (Mosate 2010). As such, they provide a critical understanding of how predicted increases in flooding variability and governance responses to that variability are likely to impact residents throughout the Delta in the future. Second, while the two villages are similar in many ways, they have distinct spatial relationships with flooding patterns. Both villages are located within a few kilometers of the floodplain, but flooding events tend to come closer to Etsha 13 and water crossed into the village during the peak floods in 2009-2011 (Shinn et al. 2014). Floods damaged molapo fields near both villages, but the damage in Etsha 13 was much more severe (ibid.). As such, the selection of these two villages provides a detailed comparison of the impacts of and responses to flooding variability over time, in addition to the micro-level spatial dimensions of flooding in this dynamic wetland landscape.

\subsection{Methods}

The methods for this research project were designed to understand environmental governance responses to changing flood patterns in the Okavango Delta. Fieldwork was completed from September 2012 - June 2013, with a follow-up trip in July 2014. Two Research Assistants helped with all interviews and surveys. Both are from Etsha 6 and are fluent in English, Setswana, and two commonly spoken tribal languages in the region, Shiyeyi and Simbukushu. 45 semistructured household interviews were conducted. Households were chosen based on primary livelihood, with an equal number participating in molapo farming, fishing, the collection of reeds and grasses, and livestock husbandry. Most interviews provided insight on multiple livelihoods, since virtually all households maintain diverse livelihood portfolios. Selective sampling was used as needed to ensure equal emphasis on gender and ethnicity. The research team also conducted randomly selected structured surveys with 20 percent of the households in each village, for a total of 185 surveys. Sampling of household interviews and surveys was designed to account for micro-level spatial variations in flooding; half of all households were located in or near the floodplain and half were located outside of the floodplain. In-depth follow up interviews were conducted with previously interviewed or surveyed households that were identified as key informants. 12 participant observation sessions were also conducted at sites of livelihood production, including in multiple molapo fields during different periods of flooding. Finally, government officials were interviewed in Etsha 6, Gumare, and Maun.

\section{Results: Increased variability and decreased adaptive capacity in the Okavango Delta}

This research resulted in four primary findings. 1) Many farmers in this region have historically used transitional agricultural practices to respond to variable flooding and precipitation patterns.

2) Power over natural resource access has shifted over time from local-level tribal leaders to the centralized national government. 3) New regulations originating at the national and international levels have decreased the long-term viability of molapo farming. 4) These changes have resulted in uncertainty about the future of this important livelihood and an overall decrease in the adaptive capacity of residents to respond to current and future environmental changes. Each of these findings is described in detail below.

\subsection{Flooding variability and transitional agriculture}

Floodplain agriculture and transitional livelihood practices are important to many residents of the Okavango Delta. Molapo fields are widely perceived to be more productive than dryland fields, 
even though floodplain fields tend to be much smaller. Molapo fields are typically only 2-3 hectares, whereas dryland fields tend to be closer to 25 hectares. According to employees at the office of Crop Production in the town of Gumare, over 90 percent of the land under molapo cultivation in the Delta region was planted with maize in 2012. Other crops grown in molapo fields include a variety of kinds of pumpkins and squash, sorghum, sweet reeds, millet, cowpeas, and beans. While floodplain agriculturalists prefer to molapo farm, they will transition temporarily to the dryland when soil conditions are too moist or too dry for producing crops in the floodplain. Household interviews confirmed that many farmers of this region have historically shifted between dryland farming and molapo farming as a way to respond to variable flooding and precipitation patterns. People explained how they plow at the dryland during the rains and go back to their molapo field when the rains stopped. Others detailed how they compensate for bad harvests in the dryland with crops from the molapo and vice versa. As one woman explained, "it is better to do both dryland and wetland farming, because you can eat the crops from the wetland while you prepare the dryland field." A government employee explained that people who engage in both farming practices garner most of their harvest from the molapo.

While molapo farming and transitional agricultural practices are designed to respond to environmental variability, the higher than average floods in 2009-2011 presented new challenges. Beginning in 2007, 47 percent of people in Etsha 6 and 85 percent of people in Etsha 13 noticed that floodwaters were getting higher. In some cases this caused maize in the molapo fields to rot before harvest. By 2009, one farmer said, "It was like we planted for nothing." Another farmer described how reeds and papyrus have grown up where she used to plow and another described how there was a hippopotamus path through his field. Some farmers reported that the higher floods caused fields to be wet all year, as opposed to drying for many months, as is more typical. One farmer said, "When one flood would come, it would find the water from the previous flood still in the field." This is likely due to the links between flooding and the groundwater table levels discussed in section 2.4. Several years of high floods would have resulted in a high groundwater table, causing molapo fields to continue to be inundated even after the inflow of water decreased beginning in 2012. Indeed, only 11 percent of surveyed households reported that they were able to continue to molapo in the years during and directly after the high floods. Farmers discussed these floods as distinct from high floods of the past. Whereas it was not uncommon to have molapo fields become unproductive for a season, they were not typically inundated for multiple years in a row and usually had time to dry out before the next flooding event occurred. As a result of this inundation of floodplain fields, many farmers decided to engage in the historical practice of temporarily transitioning to dryland farming until flooding levels returned to optimal for molapo farming. However, as described in section 4.3, new regulations have resulted in uncertainty about the continuation of this practice.

\subsection{Shifts in power in environmental governance}

There is a clear perception among residents that power has shifted over time from traditional leaders to the national government. One elder explained this is because "[The chiefs have] became closer to the government." 86 percent of surveyed households reported that the Botswana government now has control over natural resource access and that related rules originate with the national government and are then communicated and enforced at the village level through the tribal authority. As one person explained, "The chief enforces the rules and tells people about the rules at the kgotla. He is under the President and ministries." Another 
described how "The chief is supposed to tell people [the rules] ...but he is carrying out the rules determined by the national government and President." Or as one elder explained, the dikgosi are responsible for telling the people about the rules because they "live closer to the people, so they can advise those who live on the river." Related to these shifts in power, there is a strong perception among residents that rules for natural resource use have become stricter over time. As one local tribal leader explained, "It is not like it was in the old days when we did whatever we pleased. The government is serious, we have to monitor resource use." As power in Botswana has been centralized at the national level, the result has been to weaken the role of the tribal authority and traditional leaders, including in relation to natural resource use. As discussed in section 4.4, this has negative implications for the adaptive capacity of residents, including for molapo farmers.

4.3. Changing regulations: The one certificate policy and 200-meter rule

73 percent of surveyed household felt that rules over natural resources were getting stricter, with only 29 percent of people reporting this was a good thing. 77 percent of people thought rules would continue to get stricter in the future, with only 17 percent of respondents reporting that this was positive. Many of people's concerns over these changes were relevant to molapo farming. Indeed, two recent government regulations have had significant impacts on access to molapo farming. First, the government has begun to more strictly enforce an existing rule that states residents can only have one certificate for an agricultural field. This "one certificate policy" means that now if someone applies for a new dryland field, which has become more likely in recent years due to high floods, they must permanently forfeit their right to their molapo field. This ends the possibility of legally returning to that field when the floods go back down, thereby ending the continued use of transitional agricultural practices. Second, as discussed in section 2.3, the ODMP prompted regulation that prohibits any development within 200 meters of the floodplain, including molapo farming. Indeed, a number of molapo farmers reported attempts to acquire formal access to floodplain fields from the Land Board in recent years only to be told they "arrived [too] late."

Many molapo farmers discussed these new policies with a great deal of concern and commonly detailed their sense of powerlessness in the face of government requests that they shift permanently to dryland livelihoods. An older molapo farmer detailed how he had first heard of impending changes in floodplain regulations when the Etsha 6 chief told people at a kgotla meeting that the Land Board would no longer give people certificates to molapo farm. He explained that they were told that people were no longer supposed to be "in the Delta." He said that the government did not forcibly take certificates away from molapo farmers, but rather requested that people with molapo certificates turn them in to the Land Board. However, like many others, this man expressed a sense of powerlessness in the face of these requests. He said, "We did not have the power to refuse... when the government comes and tells you that you are supposed to do this, you should do it." Another farmer said, "They do not force, they come softly, with no conflict." He explained that it is like "stealing" and that "[The molapo] belongs to the government now." Another farmer explained that he is unhappy about these changes, but he will go to the dryland "because the government is in charge of everything and we have no right to refuse to relocate if the government says to."

Land Board employees confirmed the implementation of these new policies, however they 
framed them very differently than the farmers. One Land Board employee confirmed, "Someone cannot have a field at the dryland and at the [floodplain]." Another explained that transitional residency practices are "illegal, in the sense that you occupy a piece of land which you have not been allocated by the land authority.... it is what we call squatting or illegal occupation." However, government employees were careful to explain that they implement these rules not through force, but through suggestion, asking farmers things like "Why can't you revert your certificates for the fields flooded at the river and plow at the dryland?" As one explained, "We are diplomatic. If they have a certificate, we can only negotiate with them. We can never force them." One Land Board employee went so far as to suggest that they were not directly stopping anyone from growing crops in the floodplain. He explained that molapo farmers complain that, "... when I move 200 meters there will be dryness... so my crops are going to die." When asked if it is indeed possible to molapo farm more than 200 meters away from the river another employee explained that molapo farmers could use a hosepipe to irrigate from the river, as long as they first obtained a permit from the Department of Water Affairs. No mention was made of the impracticality of this due to lack of capital and resources for many of these subsistence farmers. It is clear that from the point of view of the Land Board, the government is merely making suggestions to farmers for practical responses to high flooding levels. However, the portrayal of this new policy as a mere suggestion masks the magnitude of impact for molapo farmers. Of note, one Land Board employee said, "not having access to the river is going to hit [people] really hard." This indicates some level of awareness among officials that the new rules pose significant challenges to molapo farmers, even if they are not typically acknowledged.

These new policies are not the only way in which the GOB is pressuring residents to move out of the floodplain. The government is also offering incentives for people to make this transition, while decreasing assistance for molapo farming. A local Land Board employee in Etsha 6 described forms of molapo assistance that no longer exist. For example, in the past the government would send boats to help people harvest crops during high flooding seasons. He explained that now while it is "fine to molapo farm," if crops get flooded there will no longer be any compensation. On the other hand, those who farm at the dryland are offered various kinds of assistance. For example, only farmers with land certificates can access free seeds. So if a resident no longer holds (or never held) a formal certificate for a molapo field, they are not entitled to free seeds. Further, if a person does the work of clearing their dryland field of tree stumps, the government will reportedly come to help finish plowing it with a tractor. An extension worker also detailed how the GOB is planning to make dryland farming in the area more appealing. He explained that the government wants to make the area an agricultural hub for growing millet, primarily a dryland crop. He emphasized that while people can choose to stay at the molapo, if they do so they will not be able to gain access to this new project.

These incentives seem to be working and many molapo farmers are now considering a permanent shift to the dryland. While this makes sense in the short-term while fields are still too wet to produce crops, many of these farmers are concerned that in the long-term they will not be able to return to floodplain fields when the floodwaters return to lower levels. The Land Board confirmed that in recent years more people have requested dryland plots in order to transition away from molapo farming. One employee explained that while at first people were upset with the end of molapo field allocations, "they accepted the situation because they saw ... with their own eyes that it is not good to allocate there, especially because the crops are lost to floods. So 
they are no longer upset." This further highlights the discrepancy between government and resident perceptions of moving to the dryland. While the Land Board might think people "are no longer upset," findings indicate that people have just stopped asking for molapo plots because they feel a sense of powerlessness in the situation. Whereas the government sees dryland farming as a logical solution to flooding variability, many molapo farmers feel "this means persecution and the rules are too hard." Or as another person simply put it, "If we are forced to move [to the dryland]... the government is abusing our rights."

It is apparent that the rules around molapo farming are changing, but it less clear why this is so. The chief of Etsha 13 explained how they want people to move to the dryland for safety reasons. He explained that the government is "encouraging people to go to the dryland to be safer... if you are surrounded by water you might think you are safe, but a [hippopotamus] or the floods can come and destroy your fields." Interviews with government officials in the region echoed these concerns for safety. Many residents disagree. Rather, they think changes in rules are related to broader government desires to maintain the Delta for purposes of conservation and the very lucrative high-end safari industry. As one man stated, "[The government takes] wild animals to the wetlands and takes people to the desert...for the government, wild animals are more valuable than people." An elderly molapo farmer described how people all over the Delta are getting pressured to move to the dryland and that "it is all because of tourism." Some residents reported hearing this directly from government officials. One person who recently tried and failed to get a molapo certificate said that the Land Board told him it was "because of tourism, and that people are not supposed to be in the wetland." It was not possible to verify this with government officials. Regardless of the reasons for the new regulations, these findings make clear that the power dynamic between residents and government officials are unequal.

\subsection{Decreased adaptive capacity}

These results highlight important dynamics related to environmental governance and adaptive capacity. It is clear that power over these issues lies with the government, and that people feel they have little choice but to follow rules or "suggestions" that are made by the GOB and enacted through the Tribal Authority and Land Board. Even though the government has not officially ended peoples' access to molapo farming for the time being, there is a sense among residents that access is becoming far less tenable. This is of particular concern to the many people who think flooding levels will return to optimal levels for molapo farming in the future. These people often referenced the historical context of flooding variability in the Delta, explaining that flooding of molapo fields is not a new phenomenon; in the past there was sometimes "too much water" and they would not be able to farm and in other years it would dry and they would begin to harvest from the molapo again. Molapo farmers thus live with the two types of uncertainty that challenge the long-term viability of wetland-based and transitional livelihood practices - variable flooding dynamics and stricter government edicts. While the ecological context has made it difficult for people to molapo farm in recent years, it is now issues of environmental governance that make it difficult to plan for future years of farming in the floodplain. The centralization of environmental governance with the GOB has eroded the power of local-level informal institutions and traditional authorities that used to mediate access to resources. While the dikgosi still play a minor role, their position is mainly to act as an intermediary between the GOB and local residents in their villages. As a result, government officials over 1,000 kilometers away in the capital of Gaborone are now the ones who make rules 
over access to the floodplain, and these rules continue to get stricter over time. Perhaps it is not surprising that many of these rules fail to account for the dynamic ecological conditions of the wetland environment of the Okavango Delta and the transitional livelihood strategies that have been designed to respond to them. The decrease in viability of such responsive livelihood strategies is leading to decreased adaptive capacity for many residents. As environmental variability increases as a result of climate change, residents throughout the Delta will likely also be constrained in their ability to make responsive livelihood changes due to the top-down governance approach of the GOB.

\section{Discussion}

The results of this research illustrate the social-ecological complexity of adaptive livelihood responses to environmental variability in the Okavango Delta. Floodplain and transitional agricultural livelihood strategies are important ways in which people have historically maintained household food security in this variable environment. The higher than average floods of 2009-2011 inundated molapo fields and many farmers made temporary transitions to the dryland. However, recent efforts by the GOB to more strictly regulate wetland resource use have decreased residents' access to these responsive transitional livelihood strategies and have resulted in residents feeling pressured to permanently shift to dryland livelihoods. Encouraging people to be completely dependent on dryland farming causes them to rely entirely on precipitation for irrigation, thereby increasing risk of loss of crops in the case of drought. If the climate models that predict drier future conditions for the Okavango Delta are correct, this permanent shift to the dryland could have wide reaching implications for the long-term ability of residents to respond successfully to environmental change. As such, these new regulations have reduced the current adaptive capacity of molapo farmers and others who depend on wetland resources and have implications for the future adaptive capacity of all residents who subsist from natural resource based livelihoods in this rural region.

These research findings reveal the unequal power dynamics in environmental governance in Botswana. This is particularly clear from the different ways Land Board officials and molapo farmers framed the impacts of new floodplain regulations. While government officials indicated that they are merely "suggesting" that residents focus on dryland agriculture as a practical solution to high floods, residents have internalized these suggestions as pressure to make permanent livelihood shifts to the dryland. While the government is not yet outright forcing anyone to move agricultural practices to the dryland, their strong suggestions are indeed helping them to achieve this goal as people are increasingly seeking to obtain a dryland field. As one resident explained, [the government does things] just as a parent teaches a child to walk, "Slowly, slowly so that they do not even realize it is happening."

These findings also reveal the negative impacts centralized environmental governance in Botswana can have at the local scale. Even as the ODMP sought "to sustainably use the natural resources of the Okavango Delta in an equitable way and support the livelihoods of all stakeholders (DEA 2008, xvi)," the centralized government failed to comprehend the consequences of new regulations for actors at the local level. The 200-meter rule that resulted from the ODMP shows how policy developed at higher levels and enacted through top-down governance can result in a reduction of adaptive capacity for local stakeholders. While the ODMP was developed as a well-intentioned adaptive management effort and conservation of the 
Okavango Delta is certainly necessary, these findings have striking parallels with the CBNRM efforts in the country that began with the goal of empowering local communities and ended with a re-centralization of power to the national level.

This project also raises important questions about the future of environmental governance and adaptive possibilities and for residents of the Okavango Delta region, particularly considering predictions for increasing environmental variability due to climate change. The top-down approach currently used by the GOB might provide a practical solution for some residents in the near term, but this erases the possibility for the long-term continuation of existing local-level adaptive responses that have traditionally been used by residents to respond to this variable environment. Work on adaptive management and related fields allow for the re-imagination of governance as a decentralized and responsive process, rather than as top-down and static environmental policy. As discussed in section 1, adaptive management is based on the idea that governance systems must have the ability to change practices based on new insights and experiences (Pahl-Wostl 2007) and allow for experimentation with adaptive practices to gain feedback before negative transformations occur (Ostrom 2007). This approach would necessarily embrace positive aspects of complexity and use this complexity as a way to make decisions (Bakker and Morinville 2013; Bogardi et al. 2012; Huitema et al. 2009).

In order for such an approach to be implemented in the Okavango Delta, the GOB would need to recognize the long-term implications of the one-certificate policy and 200-meter rule for the adaptive capacity of residents and then incorporate those lessons into the creation of new environmental regulations. It would also involve the creation of policy that facilitates the continuation of transitional adaptive responses to flooding variability, including shifting between dryland and floodplain agricultural practices. While seemingly minor, this change in access to natural resources would be significant for many residents. It would allow them to continue to use livelihood practices that have themselves been designed to respond to environmental variability.

More effective governance strategies might also include a polycentric approach, dispersing power over environmental decision-making across several actors that are able to respond to change (Bakker and Morinville 2013; Pahl-Wostl 2009; Huitema et al. 2009; Folke et al. 2005). Rather than concentrating decision-making in the hands of national government, some autonomous power over environmental governance would be returned to tribal authorities and other traditional leaders. This dispersion of power would allow for multiple types of response to environmental change. While the government could certainly promote dryland livelihoods as one potential option, a polycentric approach would also allow for the continuation of wetland-based and transitional livelihoods practices. This dispersal of power would need to be accounted for at all scales of governance, including with international level regulation related to the Ramsar Treaty and the Delta's recent designation as a UNESCO World Heritage Site in 2014. Decentralization efforts would have impacts for environmental governance and natural resource access throughout Botswana, far beyond the molapo fields of the Okavango Delta. It is difficult to imagine the current government enacting such changes, although the recent release of decentralization plans does offer some hope in this regard. However, this hope is tempered by the failed outcomes of previous attempts at decentralization, including CBNRM efforts and the ODMP. 


\section{Conclusion}

The findings of this project offer three related insights for broader work on adaptive environmental governance. First, they underscore the importance of accounting for the context of local settings. While the 200-meter rule was intended to promote conservation of the Okavango Delta, it also served to reduce the adaptive capacity of molapo farmers. It is clear that for adaptive management efforts to be successful, they must be sensitive to where they are being implemented and the likely impacts for local actors, including their existing livelihood strategies. Second, this research clearly indicates that adaptive management plans must consider questions of feasibility. This project confirms other findings that while the ODMP may have been an attempt at adaptive management during the development stage, it did not result in an actual devolution of authority over environmental governance to the local level (Motsumi and Cassidy 2012). This is likely due both to the centralized nature of the GOB, as well as the lack of resources of institutions at regional and local scales to oversee such projects (Magole 2008). Adaptive management efforts, and particularly polycentric approaches, must work to ensure that all necessary institutions have the capacity to make autonomous decisions. Finally, and related to the previous point, this case shows the necessity of carefully accounting for multi-scalar power relations embedded within systems of environmental governance. As seen from the research findings, residents feel they are being pressured by the centralized GOB to shift permanently to dryland livelihoods and that they are powerless to respond otherwise. This is resulting in residents making these shifts against their wishes and risks reducing their current and future adaptive capacities. As such, these findings reveal how existing power dynamics can impede adaptive management efforts and negatively impact local actors not in positions of power.

Adaptation is not determined solely by changing biophysical dynamics, but is shaped by the ability of individuals to enact their own desired response(s) to those dynamics. These complex social-ecological relationships will become increasingly pronounced as the impacts of climate change continue to disrupt sites of livelihood production and challenge existing environmental governance structures across the globe. While work from adaptive management can assist with the reimagining of more effective forms of governance, it often fails to account for on-theground realities. This research from the Okavango Delta, Botswana shows that adaptive management efforts will only be successful if they better attend to the complex relationships between changing biophysical dynamics and the multi-scalar power relationships within environmental governance systems. In so doing, adaptive management efforts can create governance strategies that result in more just responses to climate change and more robust longterm adaptive capacity for people living in increasingly variable social-ecological systems. 


\section{References}

Agrawal, Arun. "Local Institutions and Adaptation to Climate Change." Social Dimensions of Climate Change: Equity and Vulnerability in a Warming World. Washington DC, World Bank, 2010, 173-98.

Andersson, L., J. Wilk, M.C. Todd, D.A. Hughes, A. Earle, D. Kniveton, R. Layberry, and H.H.G. Savenije. "Impact of Climate Change and Development Scenarios on Flow Patterns in the Okavango River." Journal of Hydrology 331, no. 1-2 (2006): 43-57.

Armitage, Derek, Melissa Marschke, and Ryan Plummer. "Adaptive Co-Management and the Paradox of Learning." Global Environmental Change 18, no. 1 (2008): 86-98.

Armitage, Derek R., Ryan Plummer, Fikret Berkes, Robert I. Arthur, Anthony T. Charles, Iain J. Davidson-Hunt, Alan P. Diduck, et al. "Adaptive Co-Management for Social-Ecological Complexity." Frontiers in Ecology and the Environment 7, no. 2 (2008): 95-102.

Bakker, Karen, and Cynthia Morinville. "The Governance Dimensions of Water Security: A Review." Philosophical Transactions of the Royal Society A: Mathematical, Physical and Engineering Sciences 371, no. 2002 (November 13, 2013): 20130116.

Bendsen, H., and T. Meyer. "The Dynamics of the Land-Use Systems in Ngamiland: Changing Livelihood Options and Strategies." In Proceedings of the Conference on Environmental Monitoring of Tropical and Subtropical Wetlands, Maun, Botswana, 4:278-304, 2002.

Bogardi, Janos J., David Dudgeon, Richard Lawford, Eva Flinkerbusch, Andrea Meyn, Claudia Pahl-Wostl, Konrad Vielhauer, and Charles Vörösmarty. "Water Security for a Planet under Pressure: Interconnected Challenges of a Changing World Call for Sustainable Solutions." Current Opinion in Environmental Sustainability 4, no. 1 (2012): 35-43.

Boko, M., I. Niang, A. Nyong, C. Vogel, A. Githeko, M. Medany, B. Osman-Elasha, R. Tabo and P. Yanda. 2007. Africa. Climate Change 2007: Impacts, Adaptation and Vulnerability. Contribution of Working Group II to the Fourth Assessment Report of the Intergovernmental Panel on Climate Change, M.L. Parry, O.F. Canziani, J.P. Palutikof, P.J. van der Linden and C.E. Hanson, Eds., Cambridge University Press, Cambridge UK.

Department of Environmental Affairs (DEA). 2008. Okavango Delta Management Report. http://www.okacom.org/site-documents/project-reports/odmp-documents/okavangodelta-management-plan/view.

Eakin, H. C., M. C. Lemos, and D. R. Nelson. "Differentiating Capacities as a Means to Sustainable Climate Change Adaptation.” Global Environmental Change 27 (2014): 1-8.

Ellis, Frank. Rural Livelihood Diversity in Developing Countries: Evidence and Policy Implications. Overseas Development Institute London, 1999. http://dlc.dlib.indiana.edu/dlc/handle/10535/4486.

Engle, Nathan L., and Maria Carmen Lemos. "Unpacking Governance: Building Adaptive Capacity to Climate Change of River Basins in Brazil." Global Environmental Change 20, no. 1 (2010): 4-13.

Ensor, J. E., S. E. Park, E. T. Hoddy, and B. D. Ratner. “A Rights-Based Perspective on Adaptive Capacity." Global Environmental Change 31 (2015): 38-49.

Eriksen, Siri H., Andrea J. Nightingale, and Hallie Eakin. "Reframing Adaptation: The Political Nature of Climate Change Adaptation." Global Environmental Change, 2015. http://www.sciencedirect.com/science/article/pii/S0959378015300509.

Folke, Carl, Thomas Hahn, Per Olsson, and Jon Norberg. "Adaptive Governance of SocialEcological Systems.” Annu. Rev. Environ. Resour. 30 (2005): 441-73. 
Goldman, Mara J., and Fernando Riosmena. "Adaptive Capacity in Tanzanian Maasailand: Changing Strategies to Cope with Drought in Fragmented Landscapes." Global Environmental Change 23, no. 3 (2013): 588-97.

Good, Kenneth. "Resource Dependency and Its Consequences: The Costs of Botswana's Shining Gems." Journal of Contemporary African Studies 23, no. 1 (2005): 27-50.

Government of Botswana (GOB). 2014. Terms of Reference for the Development of the Decentralization Policy and Implementation Plan for Botswana. http://www.clgf.org.uk/userfiles/1/file/Decentralisation_ToRs_\%20final\%20(2).pdf

Gumbricht, T., T. S. McCarthy, and C. L. Merry. "The Topography of the Okavango Delta, Botswana, and Its Tectonic and Sedimentological Implications." South African Journal of Geology 104, no. 3 (2001): 243-64.

Haasnoot, Marjolijn, Jan H. Kwakkel, Warren E. Walker, and Judith ter Maat. "Dynamic Adaptive Policy Pathways: A Method for Crafting Robust Decisions for a Deeply Uncertain World." Global Environmental Change 23, no. 2 (2013): 485-98.

Heinl, Michael, Amy Neuenschwander, Jan Sliva, and Cornelis Vanderpost. "Interactions between Fire and Flooding in a Southern African Floodplain System (Okavango Delta, Botswana)." Landscape Ecology 21, no. 5 (2006): 699-709.

Hillbom, Ellen. "Diamonds or Development? A Structural Assessment of Botswana's Forty Years of Success." The Journal of Modern African Studies 46, no. 02 (2008): 191-214.

Hoon, Parakh. "Elephants Are like Our Diamonds: Recentralizing Community Based Natural Resource Management in Botswana, 1996-2012.” African Studies Quarterly 15, no. 1 (2014): 55.

Huitema, Dave, Erik Mostert, Wouter Egas, Sabine Moellenkamp, Claudia Pahl-Wostl, and Resul Yalcin. "Adaptive Water Governance: Assessing the Institutional Prescriptions of Adaptive (co-) Management from a Governance Perspective and Defining a Research Agenda." Ecology and Society 14, no. 1 (2009): 26.

IPCC. 2014. Climate Change 2014: Impacts, Adaptation, and Vulnerability. Part A: Global and Sectoral Aspects. Contribution of Working Group II to the Fifth Assessment Report of the Intergovernmental Panel on Climate Change. In: Field, C., Barros, V., Dokken, D., Mach, K., Mastrandrea, M., Bilir, T., Chatterjee, M., Ebi, K., Estrada, Y., Genova, R., Girma, B., Kissel, E., Levy, A., MacCracken, S., Mastrandrea, P., and White, L. (Eds.), Climate Change 2014:Impacts, Adaptation, and Vulnerability. Part A: Global and Sectoral Aspects. Contribution of Working Group II to the Fifth Assessment Report of the Intergovernmental Panel on Climate Change. Cambridge and New York: Cambridge University Press.

Kgathi, D. L, B. N Ngwenya, and J. Wilk. "Shocks and Rural Livelihoods in the Okavango Delta, Botswana." Development Southern Africa 24, no. 2 (2007): 289-308.

King, Brian. Jamie E. Shinn, Kelley A. Crews, and Kenneth R. Young. "Fluid Waters and Rigid Livelihoods in the Okavango Delta of Botswana." Land 2016 5(2): 16.

Kuruppu, Natasha, and Diana Liverman. "Mental Preparation for Climate Adaptation: The Role of Cognition and Culture in Enhancing Adaptive Capacity of Water Management in Kiribati." Global Environmental Change 21, no. 2 (2011): 657-69.

Leach, M., R. Mearns, and I. Scoones. "Environmental Entitlements: Dynamics and Institutions in Community-Based Natural Resource Management." World Development 27, no. 2 (1999): 225-47.

Leary, Neil. Climate Change and Adaptation. Earthscan, 2012. 
Lemos, Maria Carmen, and Arun Agrawal. "Environmental Governance." Annu. Rev. Environ. Resour. 31 (2006): 297-325.

Magole, Lapologang, and Kebonyemodisa Thapelo. "The Impact of Extreme Flooding of the Okavango River on the Livelihood of the Molapo Farming Community of Tubu Village, Ngamiland Sub-District, Botswana.” Botswana Notes and Records, 2005, 125-37.

McCarthy, T.S., G.R.J. Cooper, P.D. Tyson, and W.N. Ellery. "Seasonal Flooding in the Okavango Delta, Botswana - Recent History and Future Prospects." South African Journal of Science 96 (2000): 25-33.

Milzow, C., V. Burg, and W. Kinzelbach. "Estimating Future Ecoregion Distributions within the Okavango Delta Wetlands Based on Hydrological Simulations and Future Climate and Development Scenarios.” Journal of Hydrology 381, no. 1 (2010): 89-100.

Ministry of Local Government (MLG). 2014. http://www.gov.bw/en/Ministries-Authorities/Ministries/Ministry-of-Local-Government-MLG1/About-MLG/Mandate/.

Mosate, Masego. “Managing Botswana's Floods.” Government of Botswana National Disaster Management Office, June 2010. http://www.gov.bw/en/PrintingVersion/?printid=6538.

Mosepele, Ketlhatlogile, Peter B. Moyle, Glenn S. Merron, David R. Purkey, and Belda Mosepele. "Fish, Floods, and Ecosystem Engineers: Aquatic Conservation in the Okavango Delta, Botswana." BioScience 59, no. 1 (2009): 53-64.

Motsholapheko, M. R., D. L. Kgathi, and C. Vanderpost. "An Assessment of Adaptation Planning for Flood Variability in the Okavango Delta, Botswana." Mitigation and Adaptation Strategies for Global Change 20, no. 2 (2015): 221-39.

Motsholapheko, M. R., D. L. Kgathi, and C. Vanderpost. "Rural Livelihoods and Household Adaptation to Extreme Flooding in the Okavango Delta, Botswana." Physics and Chemistry of the Earth, Parts A/B/C 36, no. 14 (2011): 984-95.

Motsumi, Sekgowa, and Lin Cassidy. "Adaptive Management and Scale in a Flood-Pulsed Ecosystem - the Case of the Okavango Delta Management Plan, Botswana." Journal of Natural Resources Policy Research 4, no. 4 (2012): 271-91.

Murray-Hudson, M., P. Wolski, and S. Ringrose. "Scenarios of the Impact of Local and Upstream Changes in Climate and Water Use on Hydro-Ecology in the Okavango Delta, Botswana." Journal of Hydrology 331, no. 1-2 (2006): 73-84.

Nelson, Fred, and Arun Agrawal. "Patronage or Participation? Community-Based Natural Resource Management Reform in Sub-Saharan Africa." Development and Change 39, no. 4 (2008): 557-85.

Neuenschwander, Amy L., and Kelley A. Crews. "Disturbance, Management, and Landscape Dynamics.” Photogrammetric Engineering \& Remote Sensing 74, no. 6 (2008): 753-64.

Niang, I., O.C. Ruppel, M.A. Abdrabo, A. Essel, C. Lennard, J. Padgham, and P. Urquhart, 2014: Africa. In: Climate Change 2014: Impacts, Adaptation, and Vulnerability. Part B: Regional Aspects. Contribution of Working Group II to the Fifth Assessment Report of the Intergovernmental Panel on Climate Change [Barros, V.R., C.B. Field, D.J. Dokken, M.D. Mastrandrea, K.J. Mach, T.E. Bilir, M. Chatterjee, K.L. Ebi, Y.O. Estrada, R.C. Genova, B. Girma, E.S. Kissel, A.N. Levy, S. MacCracken, P.R. Mastrandrea, and L.L.White (eds.)]. Cambridge and New York: Cambridge University Press.

Ostrom, Elinor. "A Diagnostic Approach for Going beyond Panaceas." Proceedings of the National Academy of Sciences 104, no. 39 (2007): 15181.

Ostrom, Elinor. "Polycentric Systems for Coping with Collective Action and Global Environmental Change." Global Environmental Change 20, no. 4 (2010): 550-57. 
Ostrom, Vincent, Charles M. Tiebout, and Robert Warren. "The Organization of Government in Metropolitan Areas: A Theoretical Inquiry.” American Political Science Review 55, no. 04 (1961): 831-42.

Pahl-Wostl, Claudia. “A Conceptual Framework for Analysing Adaptive Capacity and MultiLevel Learning Processes in Resource Governance Regimes." Global Environmental Change 19, no. 3 (2009): 354-65.

Pahl-Wostl, Claudia. "Transitions towards Adaptive Management of Water Facing Climate and Global Change." Water Resources Management 21, no. 1 (2007): 49-62.

Pahl-Wostl, Claudia, and Christian Knieper. "The Capacity of Water Governance to Deal with the Climate Change Adaptation Challenge: Using Fuzzy Set Qualitative Comparative Analysis to Distinguish between Polycentric, Fragmented and Centralized Regimes." Global Environmental Change 29 (2014): 139-54.

Pelling, Mark. Adaptation to Climate Change: From Resilience to Transformation. Routledge, 2010.

Poteete, Amy R., and Jesse C. Ribot. "Repertoires of Domination: Decentralization as Process in Botswana and Senegal." World Development 39, no. 3 (2011): 439-49.

Ramsar Convention Secretariat (RCS). 2006. The Ramsar Convention Manual: a guide to the Convention on Wetlands (Ramsar, Iran, 1971), 4th ed. Ramsar Convention Secretariat, Gland, Switzerland.

Ramsar Information Sheet on Wetlands (RIS). 2006. Accessed November 1, 2014. https://rsis.ramsar.org/RISapp/files/RISrep/BW879RIS.pdf

Samatar, Abdi Ismail. An African Miracle: State and Class Leadership and Colonial Legacy in Botswana Development. Heinemann Educational Books, 1999.

Sharma, Keshav C. "Role of Traditional Structures in Local Governance for Local Development: The case of Botswana." Washington DC: World Bank, 2005. http://info.worldbank.org/etools/docs/library/153055/botswana.pdf.

Shinn, Jamie E., Brian King, Kenneth R. Young, and Kelley A. Crews. "Variable adaptations: Micro-politics of environmental displacement in the Okavango Delta, Botswana." Geoforum 57 (2014): 21-29.

Taylor, Ian. “As Good as It Gets? Botswana's' Democratic Development'.” Journal of Contemporary African Studies 21, no. 2 (2003): 215-31.

Taylor, Ian. "The Limits of the 'African Miracle': Academic Freedom in Botswana and the Deportation of Kenneth Good." Journal of Contemporary African Studies 24, no. 1 (2006): 101-22.

Tlou, Thomas. A History of Ngamiland, 1750-1906: The Formation of an African State. First. Gaborone, Botswana: Macmillan Botswana Publishing Co Pty Ltd, 1985.

Wolski, P. 2012. "Water Discharge at Mohembo.” January. http://168.167.30.198/ori/monitoring/water/index.php.

Wolski, P., and M. Murray-Hudson. "'Alternative Futures' of the Okavango Delta Simulated by a Suite of Global Climate and Hydro-Ecological Models.” Water SA 34, no. 5 (2008): 605-10.

Wolski, P., and H. H. G. Savenije. "Dynamics of Floodplain-Island Groundwater Flow in the Okavango Delta, Botswana." Journal of Hydrology 320, no. 3 (2006): 283-301. 